\title{
A new hypothesis concerning continuous distillation with stripping gas and its application in the physical refining of edible oils
}

\author{
By Manuel León-Camacho, ${ }^{a \star}$ J. C. Bada, ${ }^{b} M^{\mathrm{a}}$. M. Prieto González ${ }^{\mathrm{c}}$ and E. Graciani Constante ${ }^{\mathrm{a}}$ \\ ${ }^{a}$ Food Characterization and Quality Departament: Instituto de la Grasa (C.S.I.C). Spain. \\ ${ }^{\mathrm{b}}$ Instituto de Productos Lácteos de Asturias (C.S.I.C.), Villaviciosa, Asturias. Spain. \\ 'Universidad de Oviedo, Campus de Biseques, Energía, Gijón. Spain. \\ $\left({ }^{\star}\right.$ Corresponding author: mleon @ cica.es)
}

\begin{abstract}
RESUMEN
Una nueva hipótesis sobre la destilación en continuo con arrastre de vapor. Aplicación a la refinación física de aceites comestibles.

Se estudia la influencia de la concentración en ácidos grasos libres en el gas de arrastre en la cabeza del desodorizador durante la refinación física en continuo, y se establece una hipótesis para explicar los resultados: En un proceso continuo de desacidificación por destilación de ácidos grasos a baja presión (2 - 3 mbar), alta temperatura (180 $265^{\circ} \mathrm{C}$ ), con arrastre de vapor, con igual temperatura para los gases en la cabeza del desodorizador y para el aceite, aplicado a aceites con una acidez inicial $\leq 7,4 \%$ peso/peso, en el equilibrio se cumple que la relación entre la concentración en ácidos grasos libres en el aceite desodorizado y la concentración en ácidos grasos libres en el gas situado en la cabeza del desodorizador es constante. Esta hipótesis se somete a discusión.
\end{abstract}

PALABRAS CLAVE: Aceites comestibles - Proceso continuo de destilación con arrastre de vapor - Refinación física.

\section{SUMMARY}

A new hypothesis about continuous distillation with striping gas and its application the physical refining of edible oils.

The influence of the free fatty acid concentration in the gas inside the continuous deodorizer in continuous physical refining was studied and a hypothesis was formed to explain the results: In a continuous process of deacidification by distillation of free fatty acids at low pressure (2 - 3 mbar), high temperature $\left(180-260^{\circ} \mathrm{C}\right)$, with stripping gas, initial free fatty acid content of oil $\leq 7.4 \% \mathrm{w} / \mathrm{w}$ and similar temperature for both the gas distillate inside the continuous deodorizer and the oil, in the equilibrium the ratio between the free fatty acid content of the deacidified oil and the concentration of free fatty acids in the gas inside the continuous deodorizer is constant. This hypothesis is submitted to discussion.

KEY-WORDS: Continuous distillation with striping gas Edible oils - Physical refining.

\section{INTRODUCTION}

The oil temperature is an important operational parameter in industrial deacidification (physical refining), affecting the final free fatty acid content in the deacidified (refined) oil, the flow of stripping gas required for deodorization, the time required to reach one's goal (Graciani et al. 1994, RuizMéndez 1996) and the final quality of the oil (the content in trans fatty acids, etc) (León et al. 2001, 2003, 2004, Graciani et al. 2006, 2006a, Tubaileh et al. 2002a, 2002b). The vapor temperature inside the industrial deodorizer decreases substantially from the oil temperature and the condensation of fatty acids (known as reflux) occurs. This is a common phenomenon in industrial refining.

The effect of equal temperature of the gas distillates inside the deodorizer and the oil, was initially demonstrated by Deffense E (Deffense 1994) in the discontinuous deacidification in the laboratory. The effects and benefits of controlling the gas distillate temperature inside the discontinuous and/or continuous deodorizer during the oil deacidification (physical refining) has been discussed by Prieto et al. (Prieto et al. 1999, 2007a, 2007b, 2008a) and Bada et al. (Bada et al. 2000). Prieto et al., in their original paper entitled "Optimization of deacidification of mixtures of sunflower oil and oleic acid in a continuous process" have demonstrated that "The results showed that the oil temperature and maintaining the same temperature in the oil and the gas distillates produced the most relevant effects, having a positive effect on most of the responses" (Prieto et al. 2007b). These effects are on the final free fatty acid (on the refining oil), on the rate of free fatty acid loss (Prieto et al. 2007b) and the final quality of the oil (León et al. 2001, 2003, 2004, Graciani et al. 2006, 2006a, Tubaileh et al. 2002a, $2002 b$ ) and not on additional losses of sterols in the refining oil (2007a). However, a great increasing of the temperature from the gas distillates inside the deodorizer above that of the oil sometimes produces a small negative effect on deacidification (2007a). Heating the stripping gas above the oil inside the deodorizer does not incur a high energy cost, because the specific head of the gas is very low and the flow rate is relatively small.

The authors of this paper, in physical refining, always recommend operating with equal temperatures for the gas distillates inside the 
deodorizer and the oil. This working criterion has lead to our research group to apply for a patent for the removal the washes during deacidification (physical refining) of edible oils (Bada et al. 2008).

We therefore propose that the free fatty acid concentration in the gas inside the deodorizer in continuous physical refining is a dependent variable of the deacidification process.

The free fatty acid concentration in the gas of the deodorized process depends of the vapor pressure of the fatty acids (Bada et al. 1994, Defense 1994, Prieto et al. 2007a, Vian et al. 1964). So the variable depends on the operating temperature and absolute pressure. The new variable also depends on the deodorizer used.

In the present paper, the relationship between the free fatty acid concentration in the gas inside the continuous deodorizer and the free fatty acid concentration in the oil inside the deodorizer is studied and a hypothesis is established to explain the results:

In a process of deacidification by distillation of free fatty acids at low pressure, high temperature, with stripping gas and similar temperature for both, the gas distillate inside the continuous deodorizer and the oil, in the equilibrium, the ratio between the free fatty acid content of the deacidified oil and the concentration of free fatty acid in the gas inside the continuous deodorizer is constant at a constant temperature.

The free fatty acid content of the deacidificated oil also depends on the operating temperature, the absolute pressure, the stripping gas flow and the deodorizer used (Bada et al. 1994, Defense 1994, Prieto et al. 2007a, Vian et al. 1964).

An application of this hypothesis consists of considering the deacidification by distillation of free fatty acids in continuous as a hypothetic extraction of a component (the free fatty acids) between two fluids (oil and stripping gas) and governed by the extraction coefficient. The extraction coefficient is dependent on the solubility component of the two fluids. Therefore it depends on the variables of operation: temperature, absolute pressure and the deodorizer used.

This work was carried out in a continuous deodorizer as described by Prieto et al. (2007a, 2007b, 2008), and an adjustment to these constants is made with experimental data (constant, temperature and absolute pressure). So their application to other apparatus for physical refining involves a certain degree of extrapolation.

\section{MATERIALS AND METHODS}

The study is based on the results of 48 assays previously developed and their results reported (Prieto et al, 2007a, 2007b, 2008). The deodorizer and the operating conditions for the deacidification (physical refining) trials are shown in Table 1.

Gas free fatty acid concentration inside the continuous deodorizer $\left(\mathrm{GFFA}_{\mathrm{m}}, \mathrm{mol} / \mathrm{mol}^{-1}\right)$ was calculated as follows:
The free fatty acids distilled in $\mathrm{g} \mathrm{h}^{-1}$ for one hour are:

$$
10 \text { * }\left(\mathrm{I}_{0} \mathrm{FFA}-\mathrm{D}_{0} \mathrm{FFA}\right)^{*} \mathrm{~F}_{\mathrm{o}} \text { * } 0.9
$$

where $I_{0} F F A$ and $D_{0} F F A$ are the free fatty acid contents $(\% \mathrm{w} / \mathrm{w})$ of the initial and of the deacidified oil, respectively; $F_{\circ}$ is the flow of oil $\left(\mathrm{I} \mathrm{h}^{-1}\right)$ and 0.9 is, approximately, the oil density $\left(\mathrm{g} \mathrm{cm}^{-3}\right)$.

The equation in $\mathrm{mol} \mathrm{h}^{-1}$ would be:

10 * $\left(\mathrm{I}_{0} \mathrm{FFA}-\mathrm{D}_{\mathrm{o}} \mathrm{FFA}\right)^{*} \mathrm{~F}_{\mathrm{o}}{ }^{*} 0.9 / 282 \mathrm{~mol} \mathrm{~h}^{-1}$.

(282 $\mathrm{g}$ as average molecular weight of the free fatty acids)

The concentration of free fatty acids into the gas inside the continuous deodorizer (GFFA ${ }_{m}$ ) was calculated by the ratio between the number of mol $\mathrm{h}^{-1}$ of free fatty acids distilled and the number of mol $\mathrm{h}^{-1}$ of stripping gas $F_{\mathrm{g}}$.

$\mathrm{GFFA}_{\mathrm{m}}=10$ * $\left(\mathrm{I}_{0} \mathrm{FFA}-\mathrm{D}_{0} \mathrm{FFA}\right)^{*} \mathrm{~F}_{0}{ }^{*} 0.9 / 282$ *

where $F_{g}$ is the gas flow rate in $\mathrm{mol} \mathrm{h}^{-1}$.

The concentration of free fatty acids of the deacidified oil $(\mathrm{mol} / \mathrm{mol})$ would be:

$D_{0} F F A_{m}=10 * D_{0} F F A * 884 /(1000 * 282)$.

(884 $\mathrm{g}$ as the average molecular weight of oil).

3. RESULTS AND DISCUSSION

Table 1 summarizes the results for different trials. Columns 1 and 10 identify the trials. Columns 2-8 show the process variables: Oil flow $\left(F_{o}\right)$; oil temperature $\left(T_{0}\right)$; gas distillate temperature inside the continuous deodorizer $\left(T_{g}\right)$; total pressure; gas flow rate $\left(F_{g}\right)$; and the $I_{0} F F A$ and $D_{0} F F A$. Column 9 shows GFFA . $_{m}$.

As can be observed, the values for GFFA $\mathrm{m}_{\mathrm{m}}$ were highly variable reaching values as high as 1.105 mol of the free fatty acids per mol of stripping gas (essay 23). On the other hand, the heating of the gases in the head up to the operation temperature $\left(T_{g}=T_{0}\right)$ increases GFFA $A_{m}$ as can be confirmed by comparing the assays $1-13 ; 4-19 ; 5-6 ; 5-20 ; 6-20$;$8 ; 7-21 ; 8-21 ; 9-28 ; 10-25 ; 11-26$ and 12-44. However, the increase of $\mathrm{T}_{\mathrm{g}}$ above $\mathrm{T}_{0}$ in $20^{\circ} \mathrm{C}$ has no influence in practice (assays 21-46, $42-47$ and 4448).

Figure 1 shows the relationship between $D_{0} F F A_{m}$ and $G F F A_{m}$ for those samples in Table 1 having $T_{0}=T_{g}=240{ }^{\circ} \mathrm{C}$ and $F_{0}=3.125 \mathrm{molh}^{-1}$. A relationship between the content of free fatty acids in the deacidified oil (DoFFA ${ }_{m}$ ) and the concentration of free fatty acids in the gas $\left(\right.$ GFFA $\left._{m}\right)$ can be observed.

An interpretation of this tendency would be to consider, ideally at least, that in the continuous process of the deacidification of free fatty acids by distillation with vacuum, high temperature, stripping gas and in the indicated conditions $\left(T_{g}=T_{0}\right)$, when equilibrium is reached in the deodorizer, the ratio GFFA $_{m} / D_{o} F F A_{m}$ is constant. This constant depends on the solubility of free fatty acids into the oil and on their vapor pressure (both variables depending on the temperature) and on the type of oil. In the equilibrium, $D_{0} F F A_{m}$ and $G F F A_{m}$ are governed by this constant coefficient.

The function that relates the constant described with the independent variables of the physical 
Table 1

Results obtained in different deacidification assays

\begin{tabular}{|c|c|c|c|c|c|c|c|c|c|}
\hline \multirow{2}{*}{ Assay } & \multirow{2}{*}{$\begin{array}{c}F_{\circ} \\
I h^{-1}\end{array}$} & \multicolumn{2}{|c|}{$\mathbf{T} \stackrel{\circ}{ } \mathbf{C}$} & \multirow{2}{*}{$\begin{array}{c}\mathbf{p} \\
\text { mbar }\end{array}$} & \multirow{2}{*}{$\begin{array}{c}F_{g} \\
\mathrm{molh}^{-1}\end{array}$} & \multirow{2}{*}{$\begin{array}{l}I_{o} F F A \\
\% \text { w/w }\end{array}$} & \multirow{2}{*}{$\begin{array}{l}\text { D。FFA } \\
\% \text { w/w }\end{array}$} & \multirow{2}{*}{$\begin{array}{l}\text { GFFA }_{\mathrm{m}} \\
\mathrm{mol} / \mathrm{mol}\end{array}$} & \multirow{2}{*}{$\begin{array}{l}\text { References } \\
\text { Prieto et al. }\end{array}$} \\
\hline & & $T_{0}$ & $T_{g}$ & & & & & & \\
\hline & & \multicolumn{2}{|c|}{$T_{0}>T_{g}$} & & & & & & \\
\hline 1 & 4,8 & 226 & 173 & 2,2 & 3,125 & 3,93 & 2,70 & 0,060 & [2008] \\
\hline 2 & 3,0 & 240 & 191 & 3,9 & 1,786 & 7,40 & 1,00 & 0,343 & [2008] \\
\hline 3 & 5,0 & 240 & 195 & 10,1 & 1,785 & 7,20 & 5,20 & 0,179 & [2008] \\
\hline 4 & 3,0 & 240 & 166 & 6,8 & 3,125 & 2,50 & 1,70 & 0,025 & [2008] \\
\hline 5 & 5 & 240 & 194 & 3,2 & 3,125 & 2,50 & 0,70 & 0,092 & [2007a] \\
\hline 6 & 5 & 240 & 210 & 1,7 & 3,125 & 2,50 & 0,34 & 0,110 & [2007a] \\
\hline 7 & 5 & 240 & 199 & 1,9 & 3,125 & 7,30 & 1,90 & 0,276 & [2007a] \\
\hline 8 & 5 & 240 & 210 & 1,7 & 3,125 & 7,30 & 1,12 & 0,316 & [2007a] \\
\hline 9 & 4,8 & 245 & 166 & 2,6 & 6,250 & 3,93 & 1,64 & 0,056 & [2008] \\
\hline 10 & 5 & 260 & 192 & 3,3 & 1,786 & 2,40 & 0,60 & 0,161 & [2008] \\
\hline 11 & 5 & 260 & 209 & 2,5 & 3,125 & 2,50 & 0,38 & 0,108 & [2007a] \\
\hline \multirow[t]{2}{*}{12} & 5 & 260 & 207 & 1,9 & 3,125 & 7,30 & 0,46 & 0,349 & [2007a] \\
\hline & & \multicolumn{2}{|c|}{$T_{0}=T_{g}$} & & & & & & \\
\hline 13 & 4,8 & 226 & 226 & 2,2 & 3,125 & 3,93 & 0,73 & 0,157 & [2008] \\
\hline 14 & 4,5 & 235 & 235 & 3,9 & 3,125 & 1,92 & 0,33 & 0,073 & [2008] \\
\hline 15 & 5,0 & 240 & 240 & 10,1 & 1,786 & 2,50 & 0,14 & 0,211 & [2007b] \\
\hline 16 & 5,0 & 240 & 240 & 6,8 & 1,786 & 2,50 & 1,9 & 0,054 & [2008] \\
\hline 17 & 5,0 & 240 & 240 & 3,2 & 1,786 & 2,50 & 0,6 & 0,170 & [2008] \\
\hline 18 & 5,0 & 240 & 240 & 1,7 & 1,786 & 7,00 & 0,39 & 0,590 & [2007b] \\
\hline 19 & 3,0 & 240 & 240 & 1,9 & 3,125 & 2,50 & 0,04 & 0,075 & [2007b] \\
\hline 20 & 5,0 & 240 & 240 & 1,7 & 3,125 & 2,50 & 0,11 & 0,122 & [2007a] \\
\hline 21 & 5,0 & 240 & 240 & 2,6 & 3,125 & 7,30 & 0,64 & 0,340 & [2007a] \\
\hline 22 & 5,0 & 240 & 240 & 3,3 & 3,125 & 7,00 & 0,21 & 0,347 & [2007b] \\
\hline 23 & 5,0 & 240 & 240 & 2,5 & 3,125 & 26,33 & 4,69 & 1,105 & [2007a] \\
\hline 24 & 5,0 & 240 & 240 & 1,9 & 8,036 & 26,33 & 1,96 & 0,483 & [2007a] \\
\hline 25 & 4,5 & 245 & 245 & 2,2 & 3,125 & 1,92 & 0,49 & 0,066 & [2008] \\
\hline 26 & 4,5 & 245 & 245 & 3,9 & 1,786 & 1,92 & 0,52 & 0,113 & [2008] \\
\hline 27 & 4,8 & 245 & 245 & 10,1 & 3,125 & 3,93 & 0,31 & 0,177 & [2008] \\
\hline 28 & 4,8 & 245 & 245 & 6,8 & 6,250 & 3,93 & 0,32 & 0,088 & [2008] \\
\hline 29 & 4,5 & 255 & 255 & 3,2 & 3,125 & 1,92 & 0,11 & 0,083 & [2008] \\
\hline 30 & 5,0 & 255 & 255 & 1,7 & 3,125 & 2,90 & 0,19 & 0,138 & [2007a] \\
\hline 31 & 5,0 & 255 & 255 & 1,9 & 3,125 & 7,30 & 0,35 & 0,356 & [2007a] \\
\hline 32 & 5,0 & 255 & 255 & 1,7 & 8,036 & 15,55 & 0,12 & 0,306 & [2007a] \\
\hline 33 & 5,0 & 255 & 255 & 2,6 & 8,036 & 20,36 & 0,15 & 0,401 & [2007a] \\
\hline 34 & 5,0 & 260 & 260 & 3,3 & 1,786 & 2,50 & 0,16 & 0,209 & [2007b] \\
\hline 35 & 5,0 & 260 & 260 & 2,5 & 1,786 & 2,40 & 0,40 & 0,179 & [2008] \\
\hline 36 & 3,0 & 260 & 260 & 1,9 & 3,125 & 2,50 & 0,05 & 0,075 & [2007b] \\
\hline 37 & 5,0 & 260 & 260 & 2,2 & 1,786 & 2,50 & 0,20 & 0,205 & [2008] \\
\hline 38 & 5,0 & 260 & 260 & 3,9 & 1,786 & 7,00 & 0,20 & 0,608 & [2007b] \\
\hline 39 & 3,0 & 260 & 260 & 10,1 & 1,786 & 7,20 & 1,50 & 0,306 & [2008] \\
\hline 40 & 5,0 & 260 & 260 & 6,8 & 1,786 & 7,20 & 2,20 & 0,447 & [2008] \\
\hline 41 & 3,0 & 260 & 260 & 3,2 & 1,786 & 7,40 & 0,5 & 0,370 & [2008] \\
\hline 42 & 5,0 & 260 & 260 & 1,9 & 3,125 & 2,50 & 0,09 & 0,123 & [2007b] \\
\hline 43 & 3,0 & 260 & 260 & 1,7 & 3,125 & 7,00 & 0,09 & 0,212 & [2007b] \\
\hline \multirow[t]{2}{*}{44} & 5,0 & 260 & 260 & 2,6 & 3,125 & 7,30 & 0,33 & 0,356 & [2007a] \\
\hline & & \multicolumn{2}{|c|}{$\mathrm{T}_{\mathrm{o}}<\mathrm{T}_{\mathrm{g}}$} & & & & & & \\
\hline 45 & 5,0 & 240 & 260 & 2,0 & 3,125 & 2,50 & 0,27 & 0,114 & [2007a] \\
\hline 46 & 5,0 & 240 & 260 & 1,3 & 3,125 & 7,30 & 0,67 & 0,339 & [2007a] \\
\hline 47 & 5,0 & 260 & 280 & 1,7 & 3,125 & 2,50 & 0,13 & 0,121 & [2007a] \\
\hline 48 & 5,0 & 260 & 280 & 1,5 & 3,125 & 7,30 & 0,32 & 0,356 & [2007a] \\
\hline
\end{tabular}

Abbreviations: $F_{0}$, oil flow; $T_{0}$, oil temperature; $T_{g}$, gas distillates temperature inside the continuous deodorizer; $I_{0} F F A$ and $D_{0} F F A$, free fatty acid content of initial and deacidified oil, respectively. GFFA mols of distilled fatty acids per mol of stripping gas.

refining process (temperature and absolute pressure), is unknown. For this reason, for a small range of temperatures (between 220 and $265^{\circ} \mathrm{C}$ ) and absolute pressures (between 2 and 4 mbar), that unknown function can be equated to a second degree equation in both variables:

$\mathrm{GFFA}_{\mathrm{m}} / \mathrm{D}_{\mathrm{o}} \mathrm{FFA}_{\mathrm{m}}=\mathrm{A}+\mathrm{B}^{*} \mathrm{~T}_{\mathrm{o}}+\mathrm{C}^{\star}$ total pressure

$+D^{\star}\left(\mathrm{T}_{\mathrm{o}}\right)^{2}+\mathrm{E}^{\star}$ (total pressure $)^{2}$. 


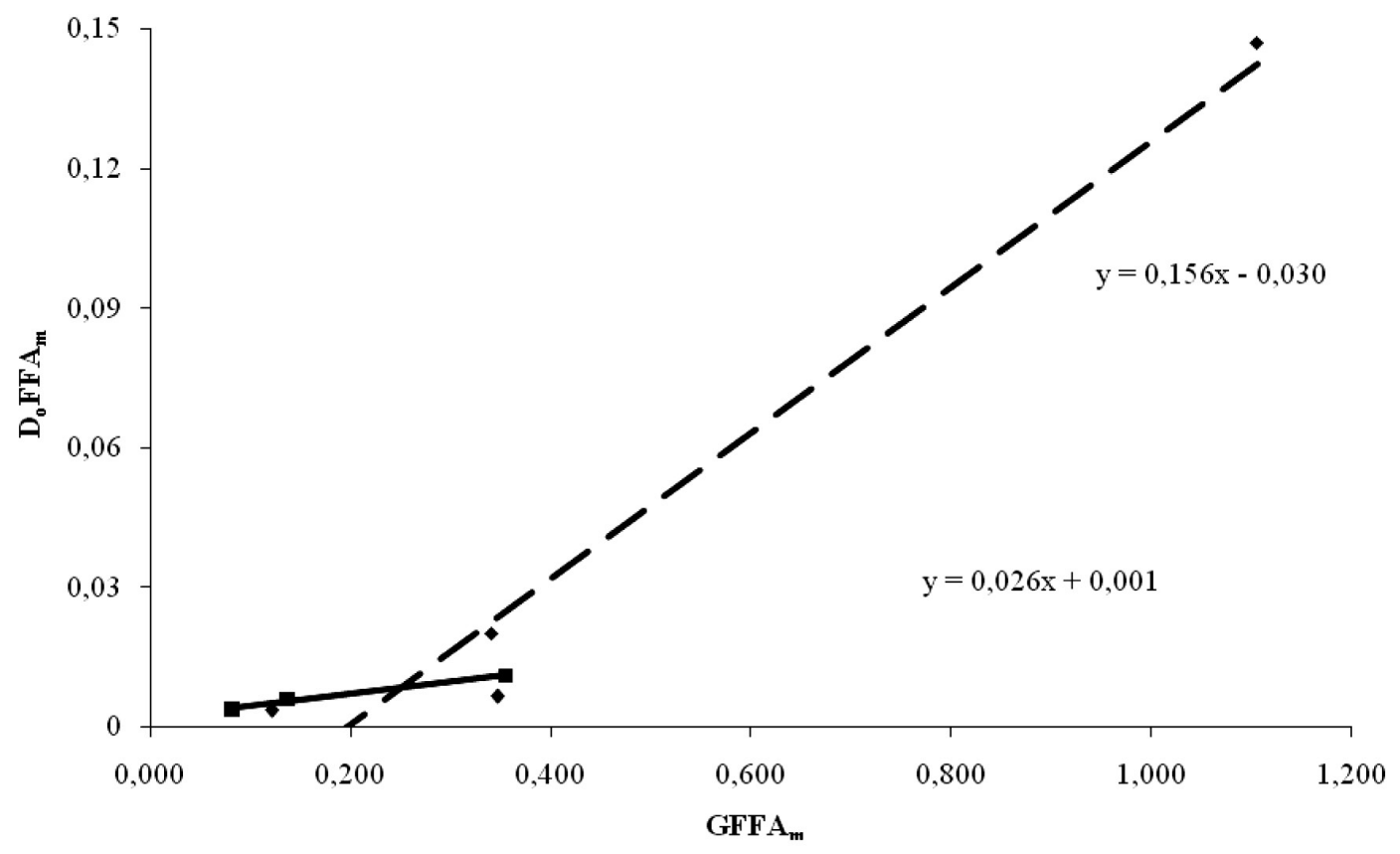

Figure 1

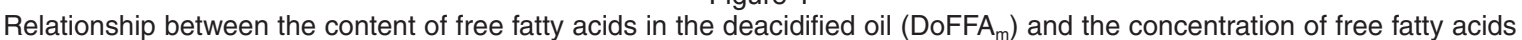
in the gas $\left(G_{F F A_{m}}\right)$. Assay no 20,21,22 and $23\left(T_{0}=240 \stackrel{\circ}{ } \mathrm{C}, T_{g}=T_{0}\right.$ and $\left.F=3,125 \mathrm{~mol} \mathrm{~h}^{-1}\right)$; assay $n^{\circ} 29,30$ and 31

$$
\left(T_{0}=255 \stackrel{\circ}{\circ}, T_{g}=T_{0} \text { and } F=3,125 \mathrm{~mol} \mathrm{~h}^{-1}\right) \text {. }
$$

According to this, an adjustment by minimum quadrates to the following equation (Davies 1965) have been used with all data (Table $1, \mathrm{~T}_{\mathrm{g}}=\mathrm{T}_{0}$ ): $\mathrm{A}=$ $-222,4 ; \mathrm{B}=1,26 ; \mathrm{C}=-4,48 ; \mathrm{D}=-0,00079 ; \mathrm{E}=$ $-0,0062$.

This interpretation shows that in equilibrium conditions $\left(T_{g}=T_{0}\right)$, for a determinate temperature and total pressure, if a determinate $D_{0} F F A$ is required, the GFFA is determined by the constant mentioned above. Therefore, $F_{g}$ depends on the free fatty acid distillates per hour (10* (I $\mathrm{I}_{0} \mathrm{FFA}-$ $\left.D_{0} F F A\right)^{*} F_{0}{ }^{*}$ density of the oils) and on the constant $D_{0}$ FFA $(\approx 0.03 \%)$.

Figure 2 corresponds to the expression of $F_{g}$. This chart is only adequate to the conditions shown in table 1. For others oils, stripping gases and

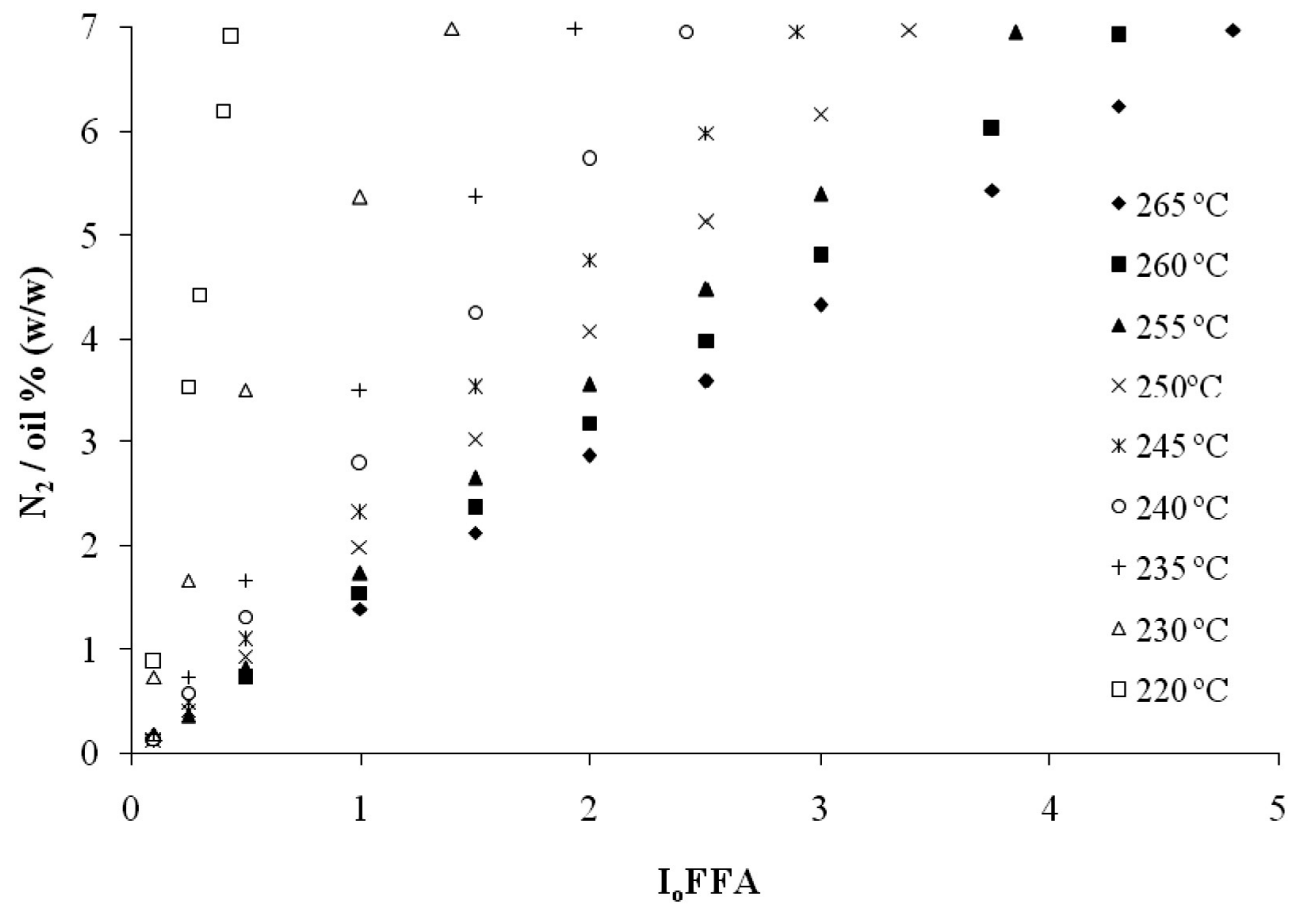

Figure 2

Continuous oil deacidification at $3 \mathrm{~mm} \mathrm{Hg}$, Oil flow of $5 \mathrm{I} \mathrm{h}^{-1}$ and free fatty acid content of the deacidified oil, $0.05 \% \mathrm{w} / \mathrm{w}$ : Relationship between the ratio of stripping gas to oil and the initial free fatty acid content of the oil ( $\left.I_{0} F F A\right)$. 
deodorizers, there will be differences due to the different solubilities of free fatty acids in oils, to the interaction of the stripping gas (steam or nitrogen) with the oil and to the deodorizer design.

The maximum rate of the stripping gas that can be used depends on the oil particles which are been stripped and is a constant of the deodorizer design for each oil height. The maximum oil flow is conditioned by the necessary residence time in the deodorizer in order to its thermal decoloration. Knowing both limits, the optimum stripping gas flow must be used to minimise costs.

\section{CONCLUSIONS}

The following hypothesis is submitted to discussion:

"In a continuous process of deacidification by the distillation of free fatty acids with stripping gas at low pressure (2-4 mbar), high temperature (180 $-265^{\circ} \mathrm{C}$ ) and similar temperature for both the gas distillate inside the continuous deodorizer and the oil, the ratio between the free fatty acid content of the deacidified oil and the concentration of free fatty acids in the gas inside the continuous deodorizer is constant in the equilibrium".

$$
\mathrm{D}_{\mathrm{o}} \mathrm{FFA}_{\mathrm{m}} / \mathrm{GFFA}_{\mathrm{m}}=\text { constant" }
$$

The application of this hypothesis consists of considering the deacidification by distillation of free fatty acids in continuous, when $\mathrm{T}_{\mathrm{g}}=\mathrm{T}_{\mathrm{o}}$, as a hypothetic extraction of a component (the free fatty acids) between the two fluids (oil and stripping gas) and governed by the partition coefficient.

According to that, the physical refining in continuous $\left(T_{g}=T_{0}\right.$ ) should be developed into steps. For a better optimization, the deodorizer should have several stages in which the distillation is carried out at different temperatures $\left(T_{g}=T_{0}\right)$, and with different flow rates for both phases (oil and stripping gas) depending on the free fatty acids to be eliminated in each stage.

According to the exposed hypothesis, to deacidify an oil with $\mathrm{I}_{0} \mathrm{FFA}=7 \% \mathrm{w} / \mathrm{w}$, the first stage would be carried out with $\mathrm{T}_{\mathrm{o}}=\mathrm{T}_{\mathrm{g}}=260^{\circ} \mathrm{C}, \mathrm{F}_{\mathrm{o}}=10$ $\mathrm{I} \mathrm{h}^{-1}$ and $\mathrm{F}_{\mathrm{g}}\left(\mathrm{N}_{2} /\right.$ oil $)=1.6 \%(\mathrm{w} / \mathrm{w})$, being $\mathrm{D}_{\mathrm{o}} \mathrm{FFA}=$ $0.35 \%(\mathrm{w} / \mathrm{w})$; and the second stage with $\mathrm{T}_{0}=\mathrm{T}_{\mathrm{g}}=$ $240 \stackrel{\circ}{\circ}, F_{\circ}=10 \mathrm{I} \mathrm{h}^{-1}$ and $\mathrm{F}_{\mathrm{g}}\left(\mathrm{N}_{2} /\right.$ oil $)=1.6 \%(\mathrm{w} / \mathrm{w})$, being $D_{0} F F A=0,03 \%(\mathrm{w} / \mathrm{w})$.

The first stage should be carried out at the appropriate temperature and stripping gas in order to distillate the residues of the sanitary treatments during seed cultivation or storage. The increase in energy cost that the industrial application of this physical refining form may involve is compensated by the improved quality of the oil obtained and the possibility of applying it to oils with acidity $>2(\%$ $\mathrm{w} / \mathrm{w}$ free fatty acids content) and in some cases with higher acidity.

In any extraction, equilibrium is achieved sooner if the contact surface between the phases increases and also if the liquid phases distance that the substance to extract has to cover until the interface between both phases decreases. The latter two criteria have been taken into account by some manufacturers in the development of new deodorizers; the first part of the deodorizer contains an adequate packing support to decrease the thickness of the oil film as much as possible in order to favor a closer contact between phases.

\section{ACKNOWLEDGMENTS}

This work was funded by The Spanish National Research and Development Program (Proyects: ALI-91-0720, Ptr.93-0061, ALI-94 716, ALI-950571, AGL 2000-1393, AGL-2001-3583), the University Institute for Industrial Technology of Asturias and the JUNTA de Andalucía (Ayuda a Grupos de Investigación). The authors express their thanks to staff members of the Instituto de la Grasa for their labor and the assistance and the coauthors of the works cited.

\section{REFERENCES}

Bada Gancedo JC, Prieto González MM, Xiberta Bernat J, Graciani Constante E, León Camacho M. 2002. Application two heating in physical refining of high-fa olive and sunflower oils. J. Am. Oil Chem. Soc. 79, 209-214.

Bada Gancedo JC, Graciani Constante E, Prieto González MMM. 2008. Procedure for the removal of fatty alcohols that produce washes, coupled to the neutralizing deodorization during the physical refining edible Oliz (Spanish patent no2 272 181).

Davies OL. 1965. Métodos estadísticos aplicados a la investigación y la producción con especial referencia a la industria química. Ed. Aguilar. Madrid. España.

Deffense E. 1994. Refinación con vapor: comparación de la teoría con la práctica. Dossier Oleo, pp 49-57.

Graciani Constante E. 2006. Los aceites y grasas. Composición y propiedades. Editorial: A. Madrid Vicente, Ediciones. ISBN no 84-87440-36-3. Editorial: Ediciones Mundi-Prensa. ISBN no 84-8476-272-6, pp. 308-315.

Graciani Constante E, Bada Gancedo JC, Rodríguez Berbel, Ruiz Méndez Mํㅡ. 1994. Physical refining of edible oils using nitrogen as stripping gas. Process optimization. Grasas y Aceites 45, 132-146.

Graciani Constante E, León Camacho M. 2006a. Esquema de un programa informático para aplicar las constantes termodinámicas de formación de ácidos grasos trans a casos prácticos que se presentan en las industrias de desodorización y/o refinación de aceites. En Graciani Constante 2006. CD-ROM: E 1.

León-Camacho M, Alvarez Serrano M, Graciani Constante E. 2004. Formación of stigmasta-3,5-diene in oilve during deodorization and/or physical refinig using nitrogen as stripping gas. Grasas y Aceites 55, 227-232.

León-Camacho M, Ruiz-Méndez MV, Graciani Constante E. 2003. Cinética de la reacción de elaidización del ácido oleico durante la desodorización y/o refinación física industrial de las grasa comestibles. Grasas y Aceites 54, 138-144.

León-Camacho M, Ruiz-Méndez MV, Graciani Constante MM, Graciani Constante E. 2001. Kinetics of the cis- 
trans isomeritation of linoleic acid in the deodorization and/or physical refining of edible fats. Eur. J. Lipid Sci. Technol. 103, 85-92.

Prieto González MM, Bada JC, Graciani E. 2007a. Temperature effects on the deacidification of mixtures of sunflower oil and oleic acid. J. Amer. Oil Chem. Soc. 84, 473-478.

Prieto González MM, Bada JC, Graciani E, Lombardía I. 1999. A comparative study of two heating procedures in the physical refining of edible oils. J. Am. Oil Chem. Soc. 76, 1471-1476.

Prieto González MM, Bada JC, León M, Graciani E. 2007b. Optimization of deacidification of mixtures of sunflower oil and oleic acid in a continuous process. J. Amer. Oil Chem. Soc. 84, 479-487.

Prieto $\mathrm{M}^{\mathrm{a}} \mathrm{M}$, Bada JC, León-Camacho M, Graciani Constante E. 2008. Deacidification and distillates recovery in the physical refining of edible oils. Eur. $J$ Lipid Sci. Techonol. 110, 101-110.
Ruiz-Méndez MV, Garrido-Fernandez A, Rodríguez Berbel, FC, Graciani Constante E. 1996. Relationships among the variables involved in the physical refining of olive oil usin nitrogen as stripping gas. Fett Lipid. 98, 121-125.

Tubaileh RM, Garrido-Fernández A, Ruiz-Méndez MV, León Camacho M, Graciani Constante E. 2002b. Effects of physical refining on contents of waxes and fatty alcohols of refined olive oil. J. Am. Oil Chem. Soc. 79, 101-104.

Tubaileh RM, Graciani Constante Mํㅗㄹ León Camacho M, López López A, Graciani, Constante E. 2002c. Kinetics of the decomposition of total aliphatic waxes in olive oil during deodorization. J. Am. Oil Chem. Soc. 79, 971-976.

Vian A, Ocón J. 1964. In Elementos de Ingeniería Química. Ed by Aguilar. Madrid. España, pp. 657.

Recibido: 24/2/09

Aceptado: $3 / 6 / 09$ 